\title{
ABSTRAK \\ PENGARUH E-PROMOTION DAN KUALITAS PRODUK TERHADAP MINAT BELI KONSUMEN PRODUK DI PT. XYZ
}

Program Studi Manajemen FBIS Universitas Buana Perjuangan Karawang

Oleh :

\section{Citra.savitri 1}

Flora Patricia Anggela 2

Email: citra.savitri@ubpkarawang.ac.id

floraanggela@ubpkarawang.ac.id

Kegiatan E-Promotion yang dilakukan oleh perusahaan terhadap produk yang dijualnya haruslah beriringan dengan kualitas produk yang dijual, karena banyaknya perusahaan yang berkompetisi perusahaan diharapkan mampu menciptakan produk yang bermutu tinggi serta berkualitas.

Penelitian ini bertujuan untuk mengetahui pelaksanaan serta besarnya pengaruh E-Promotion, kualitas produk, terhadap minat beli konsumen pada PT. Bernofarm cabang Karawang.

Metode penelitian ini menggunakan kuantitatif, dan bersifat deskriptif dan verifikatif. Dalam penelitian ini akan diuji apakah e-promotion dan kualitas produk berpengaruh terhadap minat beli konsumen. Mengingat sifat penelitian ini adalah deskriptif dan verifikatif yang dilaksanakan melalui pengumpulan data di lapangan, maka metode penelitian yang digunakan adalah metode descriptive survey dan metode explanatory survey

Hasil penelitian variabel E-Promotion menunjukan bahwa E-Promotion memiliki pengaruh yang positif dan signifikan secara parsial terhadap Minat Beli yaitu sebesar $24.8 \%$. Kualitas Produk memiliki pengaruh yang positif dan signifikan secara parsial terhadap terhadap Minat Beli yaitu sebesar 53.8\%. Berdasarkan hasil penelitian besaran angka pengaruh variabel E-Promotion adalah 24.8\% dan Variabel Kualitas Produk sebesar 53.8\%. maka dapat dinyatakan bahwa Kualitas Produk lebih banyak memberikan kontribusi terhadap Minat Beli dibandingakan dengan E-Promotion.

Berdasarkan hasil penelitian menunjukan bahwa terdapat korelasi antara $e$-promotion dengan kualitas produk sebesar $76.6 \%$.

Berdasarkan hasil penelitian ini menunjukan bahwa total pengaruh simultan E-Promotion dan Kualitas Produk sebesar 78.6\%. sedangkan sisanya $21.4 \%$ merupakan pengaruh variabel lain $(\varepsilon)$ yang tidak diteliti.

Kata Kunci : Promosi, Kualitas Produk, Minat Beli Konsumen. 


\section{PENDAHULUAN}

PT. Bernofarm semakin diakui namanya dalam dunia bisnis farmasi. Tidak hanya berbagai macam produk obat modern yang sudah diluncurkan, tetapi juga konsistensi kualitas produk dan kemajuan sumber daya manusia. Nama PT. Bernofarm diambil dari nama kota industri farmasi di Swiss, yang bernama BERN. Penemu terinspirasi pada nama dan diambil logo B dan F. Perusahaan ini bermula dari industri rumah tangga dengan satu mesin tablet. Sesuai dengan komitmen dan kerja cerdas, akhirnya tercipta cikal bakal perusahaan dengan nama CV. Sumber Farma di Surabaya, yang didirikan pada tanggal 11 Maret 1971. Berkat kerja cerdas dan loyalitas, tim PT. Bernofarm terus menerus berkembang yang mulanya 20 orang karyawan, hingga sekarang telah mempekerjakan lebih dari 1300 orang. Tahun 1976 lokasi pabrik dipindah di Jalan Buduran Sidoarjo, dan tahun 1991 mendapatkan sertifikat CPOB dari Departemen kesehatan Indonesia seiring berjalannya waktu, PT. Bernofarm semakin diakui namanya dalam dunia bisnis farmasi. Tidak hanya berbagai macam produk obat modern yang sudah diluncurkan, tetapi juga konsistensi kualitas produk dan kemajuan sumber daya manusia dikutip dari https://ecc.ft.ugm.ac.id/employer/site/view/139/profil-PT-Bernofarm (2018).

Ada dua macam jenis produk PT. XYZ yaitu ada PT. XYZ 100 dan ada PT. XYZ 30. Berikut grafik penjualan produk PT. XYZ pada tahun 2017 :

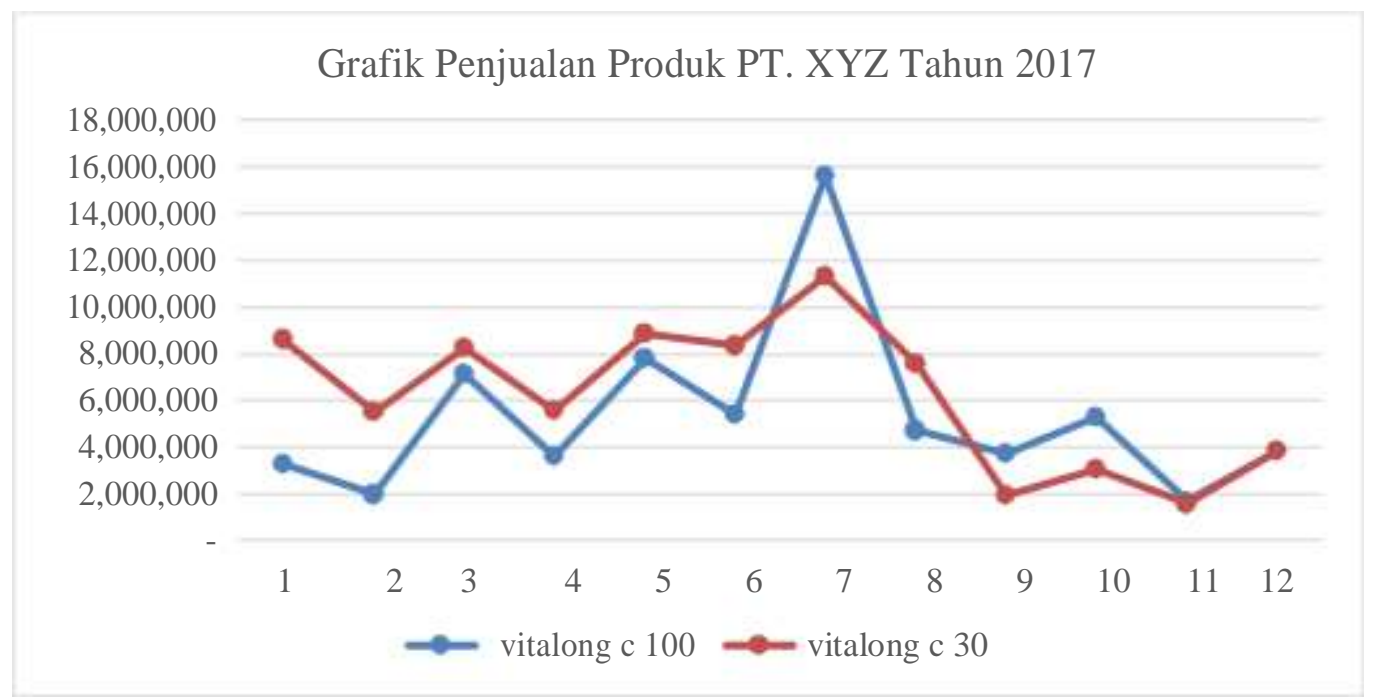

Grafik 1.1 
Grafik Penjualan Produk PT. XYZ Tahun 2017

Sumber: PT Bernofarm cabang Karawang, 2018

Berdasarkan gambar 1.1 grafik statistik di atas dapat dilihat bahwa kedua produk PT. XYZ masih cenderung tidak stabil atau fluktuatif, PT. XYZ 100 yang berwarna biru sudah mencapai penjualan sebesar 15,620,000, namun penjualan cenderung fluktuatif menurun drastis, hal ini menunjukan bahwa PT. XYZ 100 mendapatkan respon yang cukup baik dari masyarakat hanya penjualannya harus lebih agresif lagi supaya penjualan produk PT. XYZ 100 ini dapat mempertahankan posisinya dimasyarakat sehingga penjualannya diharapkan mampu berada pada grafik yang stabil.

Hasil dari penelitian Satrio Budi Prakoso (2014) bahwa Minat Beli buck store Semarang dapat dipengaruhi oleh e-promotion, brand image dan kualitas produk.

Kegiatan E-Promotion yang dilakukan oleh perusahaan terhadap produk yang dijualnya haruslah beriringan dengan kualitas produk yang dijual, karena banyaknya perusahaan yang berkompetisi perusahaan diharapkan mampu menciptakan produk yang bermutu tinggi serta berkualitas.

Pada tahun 2018 ini internet menjadi pioner yang penting dalam perkembangan bisnis, karena dengan memanfaatkan pemasaran melalui jaringan internet perusahaan akan mendapatkan pangsa pasar yang lebih luas, serta biaya yang ditimbulkan akan lebih efisien dibandingkan dengan promosi offline. Harihari belakangan ini pemasaran melalui internet biasa disebut dengan e-promotion. Selain website media E-Promotion ini bisa dilakukan dengan media sosial seperti Facebook, Youtube, Whatsupp, Line, Path, Instagram, Aplikasi Mobile, Iklan Online dan lainnya. Melalui media E-Promotion ini masyarkat akan dipermudah mengenai informasi tentang produk, alamat penjual dan manfaat produk. Jadi hari-hari ini penting bagi perusahaan untuk melakukan kegiatan marketing melalui e-promotion untuk menarik minat beli konsumen sehingga terbujuk untuk mencoba produk yang dijual. PT. Bernofarm Cabang Karawang yang masih belum secara maksimal menggunakan E-Promotion ini diduga yang menyebabkan penjualan produk PT. XYZ pada tahun 2017 dan tahun 2018 di atas masih belum mencapai target 
dari perusahaan, dengan kondisi penjulan yang cenderung tidak stabil dan fluktuatif. Waluyo Jati (2017) mengemukakan dari hasil penelitiannya bahwa Strategi Pemasaran Online (Online Marketing Strategy) berpengaruh terhadap Minat Beli Konsumen. Dari fenomena di atas maka seorang marketing PT. Bernofarm cabang Karawang harus mampu meraih potensi pasar di Karawang yang didominasi oleh kaum buruh manufaktur tersebut, dengan strategi $E$ Promotion atau promosi secara online. Selain E-Promotion yang dapat mempengaruhi Minat Beli Konsumen adalah Kualitas produk, hal ini dibuktikan oleh hasil penelitian yang dilakukan Ruri Putri Utami dan Hendra Saputra (2017) bahwa Harga Dan Kualitas Produk berpengaruh terhadap Minat Beli. Perusahaan Farmasi di Karawang cukup banyak, bahkan banyak pula perusahaan manufaktur yang ada di Karawang, ini menjadi tantangan PT. Bernofarm cabang Karawang untuk dapat tetap bersaing dengan perusahaan manufaktur lainnya. Kunci utama dari keberhasilan perusahaan manufaktur adalah kualitas produk yang berkhasiat untuk konsumen. Jadi PT. Bernofarm cabang Karawang dituntut untuk menciptakan produk yang dapat menjawab tantangan dan kebutuhan masyarakat Karawang melalui produk yang bermutu tinggi dan berkualitas.

Tujuan marketing adalah mempengaruhi keinginan konsumen untuk memilih produk yang dijual perusahaannya. Maka dari itu dengan e-promotion dan kualitas produk diharapkan minat beli konsumen dapat beralih kepada produk yang dijual oleh PT. Bernofarm cabang Karawang. Hal ini sesuai dengan penelitian yang dilakukan oleh Satrio Budi Prakoso (2014) bahwa $e$ promotion, brand image dan kualitas produk berpengaruh positif dan signifikan terhadap minat beli buck store Semarang.

Dengan demikian, dari paparan di atas penulis mengambil kesimpulan untuk memberi judul pada penulisan ini yaitu, "Pengaruh E-Promotion Dan Kualitas Produk Terhadap Minat Beli Konsumen Produk PT. XYZ PT. Bernofarm Cabang Karawang”.

Tujuan penelitian adalah untuk mengetahui, menganalisis dan membuktikan: 
1. Untuk mengetahui pelaksanaan E-Promotion pada PT. Bernofarm cabang Karawang.

2. Untuk mengetahui Kualitas Produk pada PT. Bernofarm cabang Karawang.

3. Untuk mengetahui Minat Beli Konsumen masyarakat pada PT. Bernofarm cabang Karawang.

4. Untuk mengetahui korelasi E-Promotion dengan Kualitas Produk PT. XYZ PT. Bernofarm cabang Karawang.

5. Untuk mengetahui seberapa besar pengaruh parsial E-Promotion dan Kualitas Produk Terhadap Minat Beli Konsumen Produk PT. XYZ PT. Bernofarm cabang Karawang.

6. Untuk mengetahui seberapa besar pengaruh simultan E-Promotion dan Kualitas Produk Terhadap Minat Beli Konsumen Produk PT. XYZ PT. Bernofarm cabang Karawang.

\section{TINJAUAN PUSTAKA}

Menurut Usman (2013:5-6) Manajemen berasal dari Bahasa latin, yaitu dari asal kata manus yang berarti tangan dan agere (melakukan). Kata-kata itu digabungkan menjadi managere yang artinya menangani. Kemudian diterjemahkan ke dalam bahasa inggris sebagai kata benda yaitu management yang berarti pengelolaan.

Ismail Solihin (2010:3) mengemukakan bahwa manajemen adalah upaya untuk mencapai apa yang ingin dicapai oleh perusahaan dengan memanfaatkan organisasi perusahaan mereka. Para manajer tersebut menggunakan keahlian manajerial (managerial skill) yang mereka miliki untuk mengelola berbagai sumber daya organisasi sehingga tujuan perusahaan dapat dicapai.

Dari definisi di atas dapat disimpulkan bahwa manajemen adalah ilmu atau seni dalam upaya yang dilakukan dengan dan bersama individu atau kelompok untuk mencapai tujuan organisasi.

Pemasaran menurut American Marketing Association (AMA) yang dikutip oleh Grewal dan Levy (2014:4) bahwasanya "Marketing is the activity, set of 
institutions, and processes for creating, capturing, communicating, delivering, and exchanging offerings that have value for customers, client, partners, and society at large" yang artinya "Pemasaran adalah kegiatan, mengatur lembaga, proses untuk menciptakan, mengkomunikasikan, menyampaikan, dan bertukar persembahan yang memiliki nilai bagi pelanggan, klien, dan masyarakat pada umumnya".

Sedangkan menurut Kotler dan Armstrong (2015:27) bahwasanya "Marketing as the process by which companies create value for customers build strong customer relationships in order to capture value from customers in return". Maksud dari pengertian tersebut adalah pemasaran sebagai proses dimana perusahaan menciptakan nilai bagi pelanggan dan membangun pelanggan yang kuat relationship untuk menangkap nilai dari pelanggan sebagai imbalan.

Menurut Abdurrahman dan Sanusi (2015:1) pengertian pasar secara tradisional adalah tempat berkumpulnya para pembeli dan penjual untuk membeli dan menjual barang. Sedangkan menurut Kerin dan Peterson (2015:64) pasar dapat dianggap sebagai sejumlah calon pembeli (individu atau organisasi) yang bersedia dan mampu membeli potensi penawaran (produk barang atau jasa) dari organisasi tertentu.

Dari definisi di atas dapat disimpulkan bahwa pemasaran adalah kegiatan, mengatur lembaga, proses untuk menciptakan, mengkomunikasikan, menyampaikan, dan bertukar persembahan yang memiliki nilai bagi pelanggan dan membangun pelanggan yang kuat relationship untuk menangkap nilai dari pelanggan sebagai imbalan.

Manajemen pemasaran menurut Kotler dan Keller (2012:5), mengemukakan bahwa: "Marketing management taste art and science of choosing target markets and getting, keeping, and growing customers throught creating, delivering, and communicating superior customer value". Arti dari definisi tersebut yaitu manajemen pemasaran sebagai seni dan ilmu memilih pasar sasaran dan mendapatkan, mempertahankan, serta menimgkatkan jumlah pelanggan dengan menciptakan, menghantarkan dan mengkomunikasikan nilai pelanggan yang unggul”. 
Sedangkan manajemen pemasaran menurut Suparyanto dan Rosad (2015:3) adalah ilmu yang mempelajari perencanaan, pelaksanaan, dan pengendalian terhadap produk (barang dan jasa), penetapan harga, pelaksanaan distribusi, aktivitas promosi, yang dilakukan oleh orang tertentu, dengan proses tertentu, yang ditunjang dengan bukti fisik untuk menciptakan pertukaran dalam memenuhi kebutuhan atau keinginan pelanggan, sehingga mencapai tujuan perusahaan.

Berdasarkan beberapa definisi tentang manajemen pemasaran yang telah diuraikan oleh para ahli di atas, menurut peneliti manajemen pemasaran adalah proses mempengaruhi, mendapatkan daan mempertahankan pelanggan dengan melakukan analisis, perencanaan, penerapan, dan pengendalian suatu kegiatan yang diprogramkan menciptakan pertukaran dalam memenuhi kebutuhan atau keinginan pelanggan, sehingga mencapai tujuan perusahaan.

Kotler dan Armstrong (2012:76) "promotion means activities that communicate the merits of the product and persuade target customers to buy it". Artinya promosi merupakan kegiatan yang mengkomunikasikan manfaat dari sebuah produk dan membujuk target konsumen untuk membeli produk tersebut.

Menurut Agus Hermawan (2013:38) mengemukakan bahwa Promosi adalah salah satu komponen prioritas dari kegiatan pemasaran yang memberitahukan kepada konsumen bahwa perusahaan meluncurkan produk baru yang menggoda konsumen untuk melakukan kegiatan pembelian.

Dari pendapat para ahli di atas dapat disimpulkan bahwa E-Promotion adalah kegiatan yang mengkomunikasikan manfaat dari sebuah produk dan membujuk target konsumen untuk membeli produk melalui internet seperti hal nya world of mouth online dan social media.

Produk memiliki arti penting bagi perusahaan karena tanpa adanya produk, perusahaan tidak akan dapat melakukan apapun dari usahanya. Konsumen cenderung membeli produk jika merasa cocok, karena itu produk harus disesuaikan dengan keinginan atau kebutuhan pembeli agar pemasaran produk berhasil. Dengan kata lain, pembuatan produk lebih baik diorientasikan pada keinginan pasar atau selera konsumen. Produk adalah hasil dari produksi yang 
akan dilempar kepada konsumen untuk didistribusikan dan dimanfaatkan konsumen untuk memenuhi kebutuhannya (McCharty dan Perreault, 2003).

Jadi menurut pendapat ahli di atas dapat disimpulkan bahwa kualitas produk adalah suatu kondisi dinamis yang berhubungan dengan barang, jasa, manusia, produk, dan lingkungan yang berpengaruh pada kemampuan untuk memuaskan kebutuhan yang dinyatakan atau tersirat.

David Garvin yang dikutip oleh Fandy Tjiptono dan Gregorius Chandra (2005:130) ada 8 dimensi produk yang dapat digunakan untuk menganalisis karakteristik kualitas barang, sebagai berikut:

a) Kinerja (Performance)

Berkaitan dengan aspek fungsional dari produk inti yang di beli, misalnya kecepatan, konsumsi bahan bakar, kemudahan dan kenyamanan dalam mengemudi, dan sebagainya. Merupakan karakteristik utama yang dipertimbangkan pelanggan ketika ingin membeli suatu barang.

b) Keistimewaan (Features)

Yaitu aspek kedua dari performasi yang menambah fungsi dasar berkaitan dengan pilihan-pilihan dan pengembangannya.

c) Keandalan (Reability)

Berkaitan dengan probabilitas atau kemungkinan suatu barang melaksanakan fungsinya secara berhasil dalam periobe waktu tertentu dibawah kondisi tertentu. Dengan demikian keandalan merupakan karakteristik yang merefleksikan kemungkinan atau probabilitas tingkat keberhasilan dalam penggunaan barang.

d) Konformasi (Conformance)

Berkaitan dengan tingkat kesesuaian terhadap spesifikasi yang telah ditetapkan sebelumnya berdasarkan keinginan pelanggan. Konformasi merefleksikan derajat dimana karakteristik desain produk dan karakteristik opersi memenuhi standar yang telah ditetapkan.

e) Daya tahan (Durability) 
Yaitu ukuran masa pakai suatu barang. Karakterstik ini berkaitan dengan daya tahan dari barang itu yang berkaitan dengan berapa lama produk tersebut dapat terus digunakan.

f) Kemampuan Pelayanan (Serviceability)

Yaitu karakteristik yang berkaitan dengan kecepatan, Keramahan atau kesopanan, kompetensi, kenyamanan dan kemudahan di reparasi atau perbaikan; serta penanganan keluhan secara memuaskan.

g) Estetika (Aesthetic)

Merupakan karakteristik yang bersifat subyektif sehingga berkaitan dengan pertimbangan pribadi dan refleksi preferensi individual. Dengan demikian, estetika dari suatu produk lebih banyak berkaitan dengan perasaan pribadi dan mencakup karakteristik tertentu seperti : bentuk fisik motor, yang menarik, model/desain yang artistic, warna, dan sebagainya.

h) Kualitas yang dirasakan (Perceived Quality)

Yaitu citra dan reputasi produk serta tanggung jawab perusahaan terhadapnya. Biasanya karena kurangnya pengtahuan pembeli akan atribut atau fitur produk yang akan di beli, maka pembeli mempersepsikan kualitasnya dari aspek harga, nama merk, iklan, reputasi perusahaan, maupun Negara pembuatnya (country-of-origin, country-ofmanufacture, country-of-assembly, atau country-of-brand).

Menurut Winahyu (2012) alat untuk mengukur kualitas produk sebagai berikut :

1. Kinerja

2. Kehandalan

3. Kesesuaian dengan spesifikasi

4. Daya tahan

5. Kemampuan diperbaiki

Minat beli adalah sesuatu yang diperoleh dari proses pembelajaran dan pemikiran yang membentuk suatu persepsi. Minat beli ini menciptakan suatu motivasi yang tetap terekam dalam benaknya dan menjadi suatu keinginan yang sangat kuat yang pada akhirnya ketika seorang konsumen memenuhi 
kebutuhannya akan mengaktualisasikan apa yang ada di dalam benaknya itu (Yoestini dan Rahma, 2007).

Sedangkan menurut Kotler, Bowen dan Makens (2014), minat beli timbul setelah adanya proses evaluasi alternatif. Dalam proses evaluasi, seseorang akan membuat suatu rangkaian pilihan mengenai produk yang hendak dibeli atas dasar merek maupun minat.

Faktor yang membentuk minat beli konsumen (Kotler dan Keller, 2009) yaitu:

1. Sikap orang lain

Sejauh mana sikap orang lain mengurangi alternatif yang disukai seseorang akan bergantung pada dua hal yaitu, intensitas sifat negatif orang lain terhadap alternatif yang disukai konsumen dan motivasi konsumenuntuk menuruti keinginan orang lain.

2. Faktor situasi yang tidak terantisipasi

Faktor ini nantinya akan dapat mengubah pendirian konsumen dalam melakukan pembelian. Hal tersebuttergantung dari pemikiran konsumen sendiri, apakah dia percaya diri dalam memutuskan akan membeli suatu barang atau tidak.

Dari uraian di atas dapat disimpulkan bahwa minat beli konsumen adalah sesuatu yang diperoleh dari proses pembelajaran dan pemikiran yang membentuk suatu persepsi melalui keyakinan, sikap dan perilaku konsumen.

Berdasarkan judul dari penelitian ini, peneliti membandingkan dengan penelitian sebelumnya yang relevan dengan judul penelitian yang bertujuan untuk mengetahui hubungan antar variabel dan bertujuan untuk menjadi dasar dalam penelitian yang akan dilakukan sehingga peneliti bisa lebih mudah dalam melakukan penelitiannya. Berikut perbandingan antara kesamaan dan perbedaan penelitian sebelumnya yang relevan tertera pada tabel 2.1 di bawah ini:

\section{Hubungan E-Promotion dan Kualitas Produk}

Banyak kasus yang terjadi dimasyarat bahwa ketika mereka membeli produk secara online tidak sesuai dengan apa yang mereka harapkan, artinya ada perbedaan kualitas secara visual yang ditampilkan produk secara online dengan 
kualitas produk yang nyata. Jadi dapat disimpulkan bahwa visualisasi secara online haruslah sesuai dengan kualitas produk yang diharapkan oleh konsumen sehingga konsumen tidak merasa dirugikan.

\section{Pengaruh E-Promotion terhadap Minat Beli Konsumen.}

Dengan menggunakan media online penjual dapat menjangkau lebih luas konsumen. Jangkauan promosi online ini lebih besar dan luas dari pada promosi secara konvensional. Perkembangan teknologi yang pesat dan pemerataan jaringan internet dapat menjadi peluang bagi setiap pelaku bisnis. Hal ini sesuai dengan hasil penelitian yang dilakukan oleh Waluyo Jati (2017) bahwa Terdapat hubungan positif dan signifikan antara strategi pemasaran online terhadap minat beli konsumen pada toko Online Shop Azzam Store.

\section{Pengaruh Kualitas Produk terhadap Minat Beli.}

Kuantitas produk bukan menjadi acuan akan kepuasan konsumen, namun pada saat ini komsumen lebih memilih kualitas produk dimana mereka terkadang tidak memperdulakan seberapa mahal harga produk tersebut. Hal ini menunjukan bahwa ada keterkaitan jika kualitas produk semakin baik maka minat beli konsumen semakin meningkat. Hal ini sesuai dengan hasil penelitian yang dilakukan oleh Ruri Putri Utami dan Hendra Saputra (2017) bahwa Kualitas produk juga memiliki pengaruh secara parsial Terhadap Minat Beli Sayuran Organik Di Pasar Sambas.

\section{Pengaruh E-Promotion dan Kualitas Produk terhadap Minat Beli Konsumen.}

Promotion dan Kualitas Produk terhadap Minat Beli secara parsial telah dijelaskan di atas, secara simultanpun jelas bahwa Promotion dan Kualitas Produk akan berpengaruh terhadap Minat Beli Konsumen, hal ini sesuai dengan hasil penelitian dari Satrio Budi Prakoso (2014) bahwa Hasil penelitian tersebut bahwa semua variabel independen berpengaruh positif dan signifikan terhadap minat beli melalui uji $\mathrm{F}$ dan uji T.

Berdasarkan kerangka pemikiran di atas, maka paradigma penelitian ini dapat ditunjukkan sebagaimana gambar berikut:

\section{E-PROMOTION}

1. Dapat menarik perhatian.

2. Kemenarikan gambar.

3. Informasi yang jelas.

4. Sosial media. 
Citra Savitri, Flora Patricia Anggela

Vol 4 No 2

ISSN : 2541-6995

5. Memberikan pengetahuan

E ISSN : 2580-5517 tentang produk. 


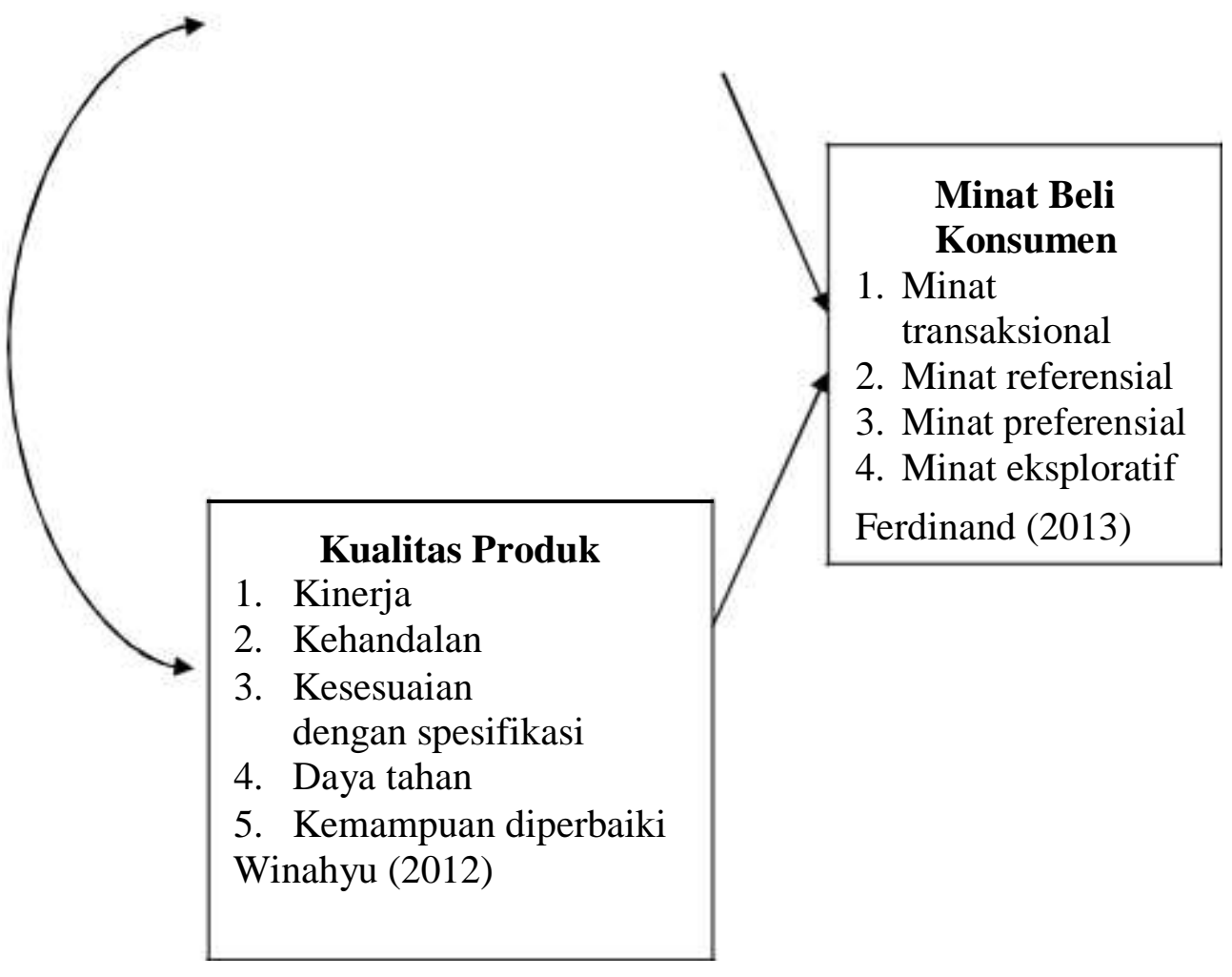

Gambar 2.1

Paradigma Penelitian

Sumber: Diolah berdasarkan sumber untuk keperluan penelitian 2018.

\section{Hipotesis Penelitian}

Berdasarkan teori dan kerangka berfikir maka hipotesis penelitian sebagai berikut :

1. Terdapat korelasi E-Promotion dengan Kualitas Produk PT. XYZ PT.

Bernofarm Cabang Karawang.

2. Terdapat pengaruh parsial E-Promotion dan Kualitas Produk terhadap Minat Beli Konsumen Produk PT. XYZ PT. Bernofarm Cabang Karawang.

3. Terdapat pengaruh simultan E-Promotion dan Kualitas Produk terhadap Minat Beli Konsumen Produk PT. XYZ PT Bernofarm Cabang Karawang. 


\section{METODE PENELITIAN}

\section{Metode Yang Digunakan}

Metode penelitian menggunakan kuantitatif, Objek penelitian yang menjadi variabel bebas dalam penelitian ini adalah e-promotion dan kualitas produk. Sedangkan yang menjadi variabel terikat adalah minat beli konsumen.

Sifat penelitian ini adalah bersifat deskriptif dan verifikatif. Penelitian deskriptif adalah penelitian yang bertujuan untuk memperoleh deskripsi tentang ciri-ciri variabel. Sifat penelitian verifikatif pada dasarnya ingin menguji kebenaran dari suatu hipotesis yang dilaksanakan melalui pengumpulan data di lapangan. Dimana dalam penelitian ini akan diuji apakah e-promotion dan kualitas produk berpengaruh terhadap minat beli konsumen. Mengingat sifat 
penelitian ini adalah deskriptif dan verifikatif yang dilaksanakan melalui pengumpulan data di lapangan, maka metode penelitian yang digunakanadalah metode descriptive survey dan metode explanatory survey.

Lokasi penelitian merupakan suatu tempat atau wilayah dimana penelitian tersebut akan dilakukan. Adapun penelitian yang dilakukan oleh penulis mengambil tempat di PT. Bernofarm cabang Karawang yang beralamat di Perumahan Bakti Praja Blok B No. 17 Karawang Barat - Jawa Barat. Tempat tersebut dipilih karena memiliki semua aspek pendukung agar penelitian dapat berjalan dengan baik.

\section{Operasionalisasi Variabel}

Definisi Operasional Variabel adalah suatu definisi mengenai variabel yang dirumuskan berdasarkan karakteristik-karakteristik variabel tersebut yang dapat diamati. Terdapat tiga variabel yang dapat di lakukan dalam penelitian ini, yakni variabel bebas (Independen Variabel) E-Promotion sebagai $\mathrm{X}_{1}$, Kualitas Produk sebagai $\mathrm{X}_{2}$, dan variabel terikat (Dependen Variabel) Minat Beli Konsumen sebagai Y.

\section{E-Promotion (X1)}

E-Promotion adalah kegiatan yang mengkomunikasikan manfaat dari produk PT. XYZ dan membujuk target konsumen untuk membeli produk melalui internet sehingga bisa menimbulkan rasa untuk membeli,seperti hal nya world of mouth online dan social media.

Alat untuk mengukur E-Promotion digunakan dimensi yang dikemukakan oleh Nuristi dan Arwiedya (2012), yaitu sebagai berikut:

1. Dapat menarik perhatian.

Menarik perhatian pelanggan dan memikat hatinya untuk terus membeli produk kita

2. Kemenarikan gambar.

Kemenarikan pesan iklan lewat gambar

3. Informasi yang jelas.

Informasi yang diberikan melalui iklan sangat jelas

4. Sosial media.

Media sosial untuk bersosialisasi dan berinteraksi secara online 
5. Memberikan pengetahuan tentang produk.

Mengingkatkan pengetahuan publik akan sebuah produk ataupun suatu perusahaan.

Untuk mengukur pelaksanaan E-Promotion digunakan skala likert dengan skor tertinggi 5 (sangat baik) dan terendah 1 (sangat tidak baik).

\section{Kualitas Produk (X2)}

Kualitas produk adalah suatu kondisi dinamis yang berhubungan dengan barang, jasa, manusia, produk, dan lingkungan yang berpengaruh pada kemampuan untuk memuaskan kebutuhan yang dinyatakan atau tersirat.

Alat untuk mengukur Kualitas Produk digunakan dimensi yang dikemukakan oleh Winahyu (2012) sebagai berikut:

6. Kinerja

Dimensi ini menyangkut karakteristik fungsi produk. Maksudnya sejauh mana produk dapat berfungsi sebagaimana fungsi utama produk tersebut.

7. Kehandalan

Dimensi ini menyangkut kemungkinan tingkat kegagalan pemakaian. Artinya, apakah produk sering tidak dapat dioperasikan sesuai fungsi utama karena adanya masalah-masalah teknis ataukah lancar-lancar saja.

8. Kesesuaian dengan spesifikasi

Dimensi ini berkaitan dengan seberapa lama produk dapat terus digunakan selama jangka waktu tertentu

9. Daya tahan

Dimensi ini berkaitan dengan seberapa lama produk dapat terus digunakan selama jangka waktu tertentu.

10. Kemampuan diperbaiki

Dimensi ini melihat kualitas barang dari kemudahan untuk pengoperasian produk dan kemudahan perbaikan maupun komponen pengganti.

Untuk mengukur pelaksanaan Kualitas Produk digunakan skala likert dengan skor tertinggi 5 (sangat baik) dan terendah 1 (sangat tidak baik). 


\section{Minat Beli $(Y)$}

Minat Beli Konsumen adalah sesuatu yang diperoleh dari proses pembelajaran dan pemikiran yang membentuk suatu persepsi melalui keyakinan, sikap dan perilaku konsumen.

Alat untuk mengukur Minat Beli Konsumen digunakan dimensi yang dikemukakan oleh Ferdinand (2013) dimensi-dimensi utama membentuk citra sebuah merek tertuang dalam berikut ini:

1. Minat transaksional, yaitu kecenderungan seseorang untuk membeli produk.

2. Minat referensial, yaitu kecenderungan seseorang untuk mereferensikan produk kepada orang lain.

3. Minat preferensial, yaitu minat yang menggambarkan perilaku seseorang yang memiliki prefrensi utama pada produk tersebut. Preferensi ini hanya dapat diganti jika terjadi sesuatu dengan produk prefrensinya.

Menurut Sugiyono (2017 : 81) yang dimaksud dengan sampel adalah sebagai berikut : "Dalam penelitian kuantitatif sampel adalah bagian dari jumlah dan karakteristik yang dimiliki oleh populasi tersebut."

Sampel digunakan sebagai ukuran sampel dimana ukuran sampel merupakan suatu langkah untuk mengetahui besarnya sampel yang akan diambil dalam melaksanakan suatu penelitian. Kemudian besarnya sampel tersebut biasanya diukur secara statistika ataupun estimasi penelitian. Selain itu juga diperhatikan bahwa sampel yang harus dipilih representative. Artinya segala karakteristik populasi hendaknya tercermin dalam sampel yang dipilih.

Untuk menghitung jumlah sample dari populasi tertentu, maka digunakan rumus Slovin sebagai berikut :

\footnotetext{
$=$

$1++^{2}$

Keterangan:

: Sampel

$\mathrm{N}$ : Populasi
} 


\section{e : Taraf kesalahan atau nilai kritis}

Pengambilan sampel ini dilakukan pada tingkat kepercayaan $90 \%$ atau nilai kritis $10 \%$ sehingga ukuran sampel dapat dihitung sebagai berikut:

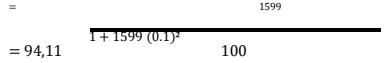

Berdasarkan pehitungan diatas tersebut maka sample yang diambil sebanyak 100 orang.

\section{Teknik Pengumpulan Data}

Pengumpulan data yang lengkap, baik untuk data sekunder beserta fenomenanya, maupun data primer tentang persepsi dilakukan melalui kegiatan survei. Data yang diperlukan dari kedua jenis data tersebut dikumpulkan dengan teknik sebagai berikut :

\section{Kuesioner / Angket}

Kuesioner atau angket digunakan untuk mengumpulkan data primer dengan menggunakan daftar pertanyaan yang disusun sesuai tujuan penelitian untuk dibagikan kepada responden.

\section{Teknik Observasi}

Observasi, mengadakan pengamatan langsung untuk memperoleh informasi lain yang belum dapat diperkirakan sebelumnya, menelaah dan mengkaji catatan/ laporan tahunan, dokumen-dokumen lain dari berbagai lembaga yang ada kaitannya dengan permasalahan yang akan diteliti.

3. Wawancara

Teknik wawancara digunakan untuk mendalami dan memperkuat variabel yang diteliti pada penelitian ini, wawancara dilakukan dengan konsuemen pada lokus penelitian.

\section{Transformasi Data}

Data variabel yang terkumpul melalui kuesioner dalam penelitian ini berbentuk data ordinal, sedangkan untuk menganalisis data dengan analisis jalur diperlukan data dengan ukuran paling tidak berskala interval. Maka dari itu, data 
tersebut ditransformasikan menjadi data berskala interval dengan method of successive (MSI). Berikut tahapan-tahapan method of successive (MSI):

1. Menentukan frekuensi setiap respon.

2. Menentukan proporsi setiap respon dengan membagi frekuensi dengan jumlah sampel.

3. Menjumlahkan proporsi secara berurutan untuk setiap respon, sehingga diperoleh proporsi kumulatif.

4. Menentukan $\mathrm{Z}$ untuk masing-masing proporsi kumulatif yang dianggap menyebar mengikuti sebaran normal baku. Nilai $\mathrm{Z}$ diperoleh dari tabel distribusi normal baku.

5. Dengan menggunakan tabel distribusi normal standar kita tetukan nilai $\mathrm{Z}$

()$=\frac{1}{\overline{\sqrt{2}}}\left(-\mathrm{C}^{2}\right)$

6. Menghitung Scale Value (SV) untuk masing-masing respon

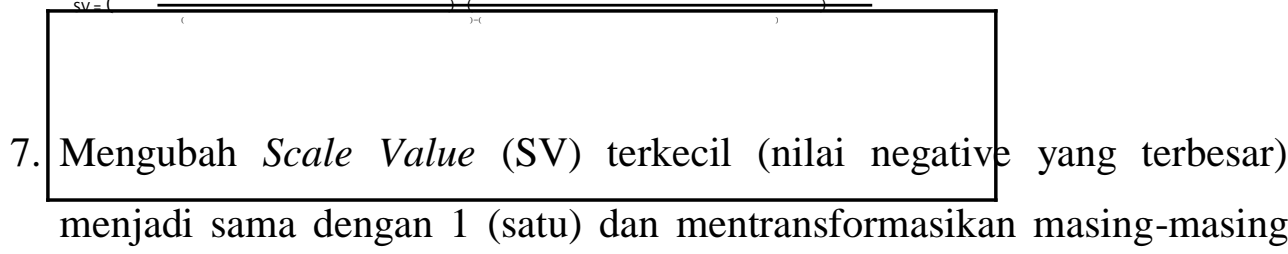
skala menurut perubahan skala terkecil, sehingga diperoleh transformed scale value (TSV). Mentransformasikan nilai skala dengan menggunaka rumus:

$$
Y=S V+\mid S V \min
$$

\section{HASIL DAN PEMBAHASAN}

\section{Kelengkapan Informasi di Website}

Kelengkapan informasi di website yaitu bertujuan untuk mempermudah konsumen mendapatkan informasi yang lengkap dengan mudah, hasil data dari penyebaran kuesioner dari penelitian. 
Berdasarkan gambar di atas, maka dapat dijelaskan bahwa jumlah responden sebanyak 100 orang berpendapat tentang indikator keunikan tampilan promosi di website dengan total skor sebanyak 367 yang terletak pada posisi bar scale baik.

Pelaksanaan variabel minat beli untuk indikator tingkat keinginan untuk membeli produk PT. XYZ dalam jangka pendek yaitu tinggi ditunjukan dengan angka $54 \%$, cukup tinggi $33 \%$, sangat tinggi $12 \%$, rendah $1 \%$ dan sangat rendah $0 \%$.

Dinilai koefisiensi korelasi antar variabel bebas yaitu E-Promotion dan Kualitas Produk adalah 0.766, korelasi tersebut dapat dijelaskan dengan gambar di bawah ini:

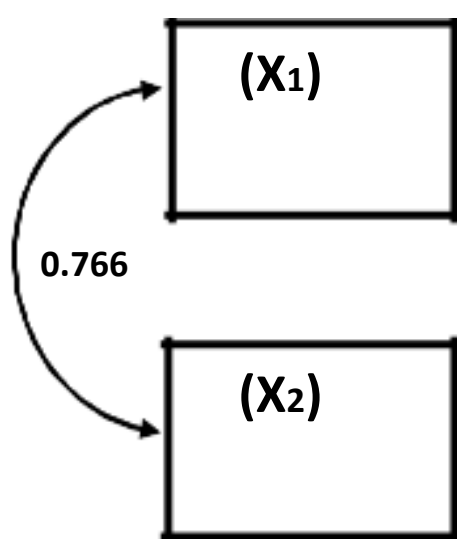

\section{Gambar 4.49}

\section{Korelasi Antar Variabel}

Sumber: Hasil Analisis Data, 2019

Sumber : Sugiyono (2018: 287)

Penjelasan dari tabel diatas yaitu hubungan antara variabel e-Promotion dan kualitas produk terdapat nilai sebesar 0,766 sehingga apabila dikonsultasikan dengan tabel interpretasi nilai $\mathrm{r}$ (korelasi), mempunyai tingkat hubungan yang kuat dan searah. Pertanyaan diatas dapat diartikan apabila $E$ Promotion naik sebesar satu satuan, maka diikuti dengan kenaikan Kualitas Produk sebesar 0,766 satuan. 


\section{Analisis Jalur/Path Analysis}

Hasil Analisis menggunakan program SPSS versi 16.0 telah didapatkan koefisien jalur dari setiap variabel yaitu variabel E-Promotion dan Kualitas Produk terhadap Minat Beli konsumen

\section{Analisis Pengaruh Parsial E-Promotion (X1) terhadap Variabel Minat Beli} (Y)

Berdasarkan tabel 4.62 dapat dijelaskan bahwa pengaruh parsial variabel E Promotion (X1) terhadap variabel Minat Beli (Y) terdapat nilai sebesar 0.312, sehingga dapat diperoleh persamaan Minat Beli (Y) sebesar 0.312 dapat digambarkan pada gambar dibawah ini:

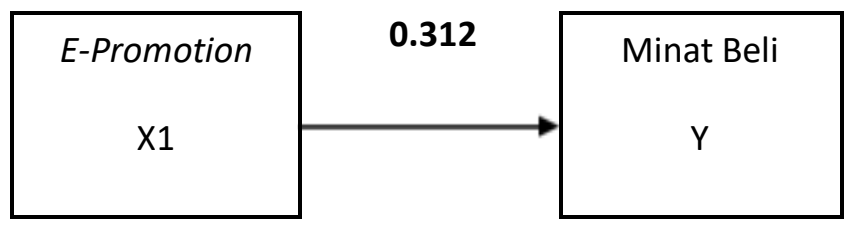

Gambar 4.50

Pengaruh Parsial X1 terhadap Y

Sumber: Hasil Analisis Data, 2019

\section{b) Analisis Pengaruh Parsial Variabel Kualitas Produk (X2) Terhadap}

\section{Variabel Minat Beli (Y)}

Berdasarkan tabel 4.62 dapat dijelaskan bahwa pengaruh parsial variabel Kualitas Produk (X2) terhadap variabel Minat Beli (Y) terdapat nilai sebesar 0.624, sehingga dapat diperoleh persamaan Minat Beli (Y) sebesar 0.624 dapat digambarkan pada gambar dibawah ini:

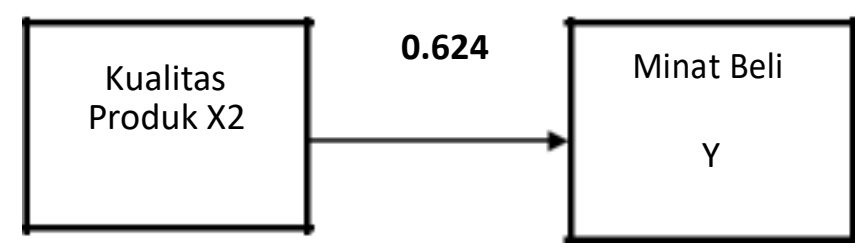

\section{Gambar 4.51}

Pengaruh Parsial $\mathrm{X}_{2}$ terhadap Y

Sumber: Hasil Analisis Data, 2019

Dari hasil koefisien jalur variabel E-Promotion (X1) terhadap variabel Minat Beli (Y) dan hasil koefisien variabel kualitas produk (X2) terhadap variabel minat beli (Y) dapat digambarkan sebagai berikut: 


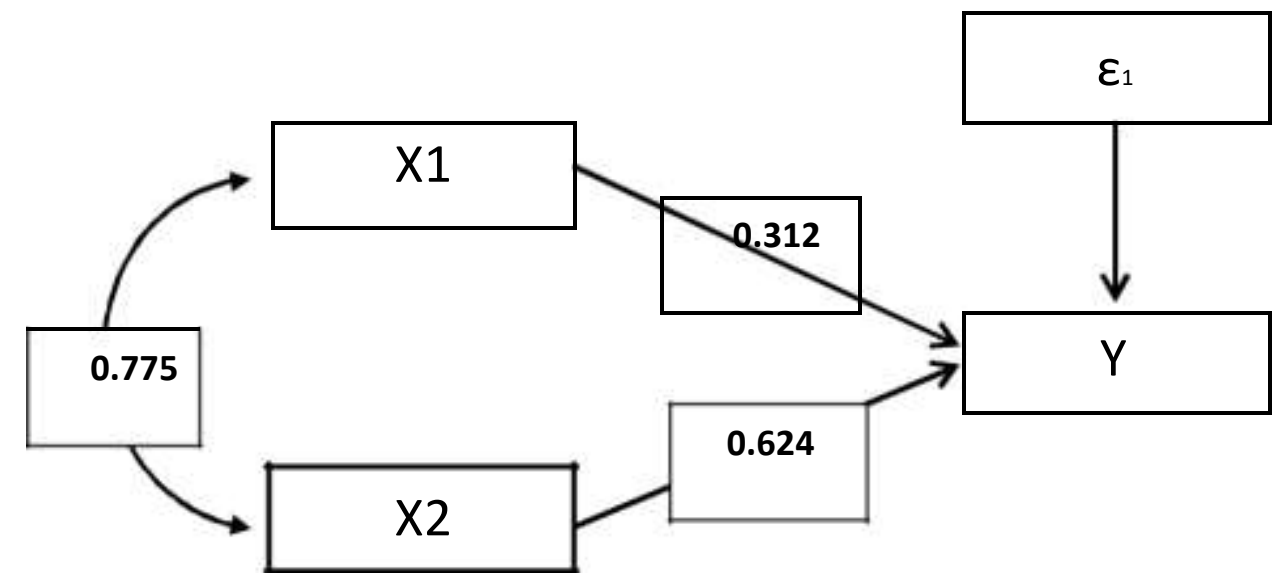

\section{Gambar 4.52}

Pengaruh Parsial Variabel E-Promotion (X1) dan Kualitas Produk (X2) terhadap Minat Beli (Y)

Sumber: Hasil Analisis Data, 2019

Berdasarkan gambar diatas menunjukan bahwa besaran derajat asosiatif atau koefisien jalur Variabel E-Promotion 0.312 lebih rendah dari variabel Kualitas Produk 0.624. Adapun persamaan jalurnya adalah sebagai berikut:

$$
Y=0.312 X 1+0.624 X 2+\varepsilon
$$

Keterangan :

$$
\begin{array}{ll}
\mathrm{X} 1 & =\text { E-Promotion } \\
\mathrm{X} 2 & =\text { Kualitas Produk } \\
\mathrm{Y} & =\text { Minat Beli } \\
\varepsilon & =\text { Variabel lain yang tidak diukur tetapi mempengaruhi Y }
\end{array}
$$

\section{Analisis Pengujian Hipotesis}

a. Uji Parsial E-Promotion Terhadap Minat Beli

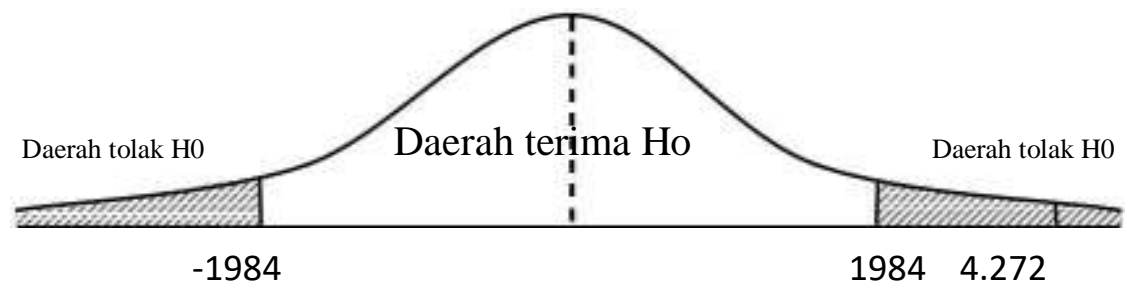

Gambar 4.53 


\section{Kurva Pengujian Pihak Kanan E-Promotion terhadap Minat Beli} Sumber: Hasil Olahan Penelitian, 2019

Berdasarkan gambar diatas dapat diketahui kurva pengujian pihak kanan E-Promotion terhadap Minat Beli bahwa hipotesis nol ditolak sehingga ada pengaruh positif dan signifikan antar E-Promotion terhadap Minat Beli.

b. Uji Parsial Kualitas Produk Terhadap Minat Beli

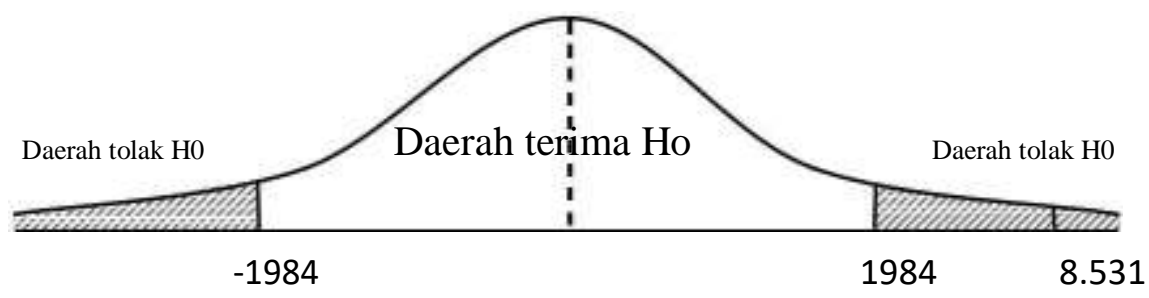

Gambar 4.54

Kurva Pengujian Pihak Kanan Kualitas Produk terhadap Minat Beli Sumber: Hasil Olahan Penelitian, 2019

Berdasarkan gambar diatas dapat diketahui kurva pengujian pihak kanan Kualitas Produk terhadap Minat Beli bahwa hipotesis nol ditolak sehingga ada pengaruh positif dan signifikan antar E-Promotion terhadap Minat Beli.

c. Uji Simultan E-Promotion dan Kualitas Produk Terhadap Minat Beli

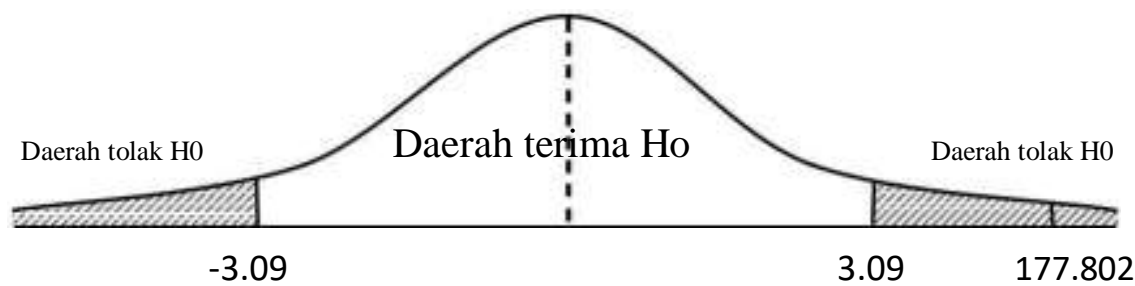

Gambar 4.55

Kurva Pengujian Pihak Kanan E-Promotion dan Kualitas Produk terhadap Minat Beli

Sumber: Hasil Olahan Penelitian, 2019

Berdasarkan gambar diatas dapat diketahui kurva pengujian pihak kanan E-Promotion dan Kualitas Produk terhadap Minat Beli bahwa hipotesis nol ditolak sehingga ada pengaruh positif dan signifikan antar E-Promotion terhadap Minat Beli PT. XYZ.

\section{Pembahasan Deskriptif}

Adapun pembahasan desktiptif mengenai masing-masing variabel dalam penelitian ini dapat diuraikan sebagai berikut: 
1. Berdasarkan hasil penelitian variabel E-Promotion menunjukan bahwa dari 15 pernyataan variabel E-Promotion dengan nilai total rentang skala sebesar 5527 dan modus sebesar 417 berada pada daerah baik yang artinya bahwa keadaan E-Promotion produk PT. XYZ di PT. Bernofarm Cabang Karawang masih baik.

2. Berdasarkan hasil penelitian Variabel Kualitas Produk menunjukan bahwa dari 15 pernyataan variabel Kualitas Produk dengan nilai total rentang skala sebesar 5764 dan modus sebesar 409 berada pada daerah baik yang artinya bahwa keadaan Kualitas Produk di PT. Bernofarm Cabang Karawang masih baik.

3. Berdasarkan hasil penelitian Minat Beli menunjukan bahwa dari 15 pernyataan variabel Minat Beli dengan nilai total rentang skala sebesar 5800 dan modus sebesar 406 berada pada daerah baik yang artinya bahwa keadaan Minat Beli di PT. Bernofarm Cabang Karawang masih baik.

\section{Pembahasan Verifikatif}

Adapun pembahasan dari metode verifikatif dalam penelitian ini dapat diuraikan sebagai berikut:

\section{Pengaruh Parsial E-Promotion dan Kualitas Produk terhadap Minat Beli}

a. Berdasarkan hasil penenelitian ini E-Promotion memiliki pengaruh yang positif dan signifikan secara parsial terhadap Minat Beli yaitu sebesar 24.8\%. Hal ini sejalan dengan penelitian yang dikemukakan oleh Riska Lady Meitharani Budi Astuti (2016), dengan judul penelitian " Pengaruh Promosi Online dan Celebrity Endorser terhadap Minat Beli Konsumen Tas Online Shop Fani House “ Skripsi Universitas Diponegoro, yang menyatakan dalam hasil penelitianya bahwa promosi online (X1) berpengaruh positif terhadap minat beli (Y).

b. Berdasarkan hasil penenelitian ini Kualitas Produk memiliki pengaruh yang positif dan signifikan secara parsial terhadap terhadap Minat Beli yaitu sebesar 53.8\%. Hal ini sejalan dengan penelitian yang dikemukakan oleh Ruri Putri Utami dan Hendra Saputra (2017), dengan judul penelitian “ Pengaruh Harga Dan Kualitas Produk Terhadap Minat Beli Sayuran Organik Di Pasar Sambas Medan “, jurnal Niagawan, yang 
menyatakan dalam hasil penelitiannya bahwa kualitas produk secara parsial berpengaruh signifikan terhadap minat beli. Berdasarkan hasil penelitian besaran angka pengaruh variabel E-Promotion adalah $24.8 \%$ dan Variabel Kualitas Produk sebesar 53.8\%. maka dapat dinyatakan bahwa Kualitas Produk lebih banyak memberikan kontribusi terhadap Minat Beli dibandingakan dengan E-Promotion.

\section{Korelasi antara variabel E-Promotion dengan variabel Kualitas Produk}

Berdasarkan hasil penelitian menunjukan bahwa terdapat korelasi antara e- promotion dengan kualitas produk sebesar $76.6 \%$.

\section{Pengaruh Simultan (Bersama-Sama) E-Promotion dan Kualitas Produk terhadap Minat Beli}

Berdasarkan hasil penelitian ini menunjukan bahwa total pengaruh simultan E-Promotion dan Kualitas Produk sebesar 78.6\%. sedangkan sisanya $21.4 \%$ merupakan pengaruh variabel lain $(\varepsilon)$ yang tidak diteliti.

\section{KESIMPULAN DAN SARAN}

\section{Kesimpulan}

Berdasarkan hasil penelitian mengenai pengaruh E-Promotion dan Kualitas Produk terhadap Minat Beli Konsumen PT. XYZ PT. Bernofarm Cabang Karawang dapat diambil saran sebagai berikut:

1. E-Promotion di PT. Bernofarm Cabang Karawang khususnya produk PT. XYZ memiliki pengaruh namun masih rendah, artinya PT. Bernofarm harus melakukan strategi dalam meningkatkan e-promotion. Salah satunya dengan meningkatkan informasi produk melalui online seperti facebook dan instragram.

2. Kualitas Produk di PT. Bernofarm Cabang Karawang khususnya produk PT. XYZ berada di kriteria yang baik hal ini menunjukan bahwa Kualitas Produk bisa ditingkatkan kepada Kualitas Produk yang sangat baik, karena Kualitas Produk dalam suatu produk sangat penting untuk meningkatkan minat beli konsumen bahkan hasil dari penelitian ini menunjukan Kualitas 
Produk lebih unggul dibandingkan dengan E-Promotion terhadap Minat Beli konsumen.

3. Minat Beli konsumen PT. XYZ berada di kriteria yang baik hal ini menujukan bahwa konsumen produk PT. XYZ sudah baik hanya perlu ditingkatkan lagi dibagian E-Promotion dan Kualitas Produk agar Minat Beli Konsumen bisa berada diposisi sangat baik.

4. Terdapat korelasi antara variabel E-Promotion dengan variabel Kualitas Produk, hal ini berdasarkan penelitian dengan nilai sebesar $76.6 \%$.

5. Terdapat pengaruh yang positif dan signifikan secara parsial antara variabel E-Promotion terhadap variabel Minat Beli hal ini berdasarkan penelitian dengan nilai sebesar $24.8 \%$. Terdapat pengaruh yang positif dan signifikan secara parsial antara variabel Kualitas Produk terhadap variabel Minat Beli hal ini berdasarkan penelitian dengan nilai sebesar 53.8\%.

6. Terdapat pengaruh yang positif dan signifikan secara simultan antara variabel E-Promotion dan variabel Kualitas Produk terhadap variabel Minat Beli. Berdasarkan hasil penelitian ini menujukan total pengaruh simultan EPromotion dan Kualitas Produk terhadap Minat Beli yaitu dengan nilai sebesar $78.6 \%$, sedangkan sisanya $21.4 \%$ merupakan pengaruh variabel lain (ع) yang tidak diteliti.

\section{Saran}

Berdasarkan hasil penelitian mengenai pengaruh E-Promotion dan Kualitas Produk terhadap Minat Beli Konsumen PT. XYZ PT. Bernofarm Cabang Karawang dapat diambil saran sebagai berikut:

1. Penelitian ini memiliki keterbatasan hanya menggunakan variabel EPromotion dan Kualitas Produk untuk mengetahui pengaruh konsumen untuk mempunyai Minat Beli produk PT. XYZ, sehingga perlu penelitian selanjutnya untuk mengetahui factor lain yang mempengaruhi minat beli konsumen yang mungkin bisa dipengaruhi dari harga dan bisa dari adanya event marketing sehingga minat beli konsumen PT. XYZ di PT. Bernofarm Cabang Karawang dapat tercapai.

2. Berdasarkan hasil penelitian yang diperoleh penulis tentang E-Promotion dan Kualitas Produk yang masuk ke kategori baik, masih banyak yang harus 
Citra Savitri, Flora Patricia Anggela

Vol 4 No 2

ISSN : 2541-6995

E ISSN : 2580-5517

ditingkatkan agar bisa mencapai posisi sangat baik, salah satunya dengan melakukan promosi yang lebih agresif lagi dan terus meningkatkan kualitsa produk,sehingga konsumen memiliki minat beli yang tinggi, apabila konsumen sudah membeli produk kemudian merasa puas dengan kualitas produk yang telah diberikan dan konsumen sudah merasakan manfaat produk yang kita jual pasti konsumen tersebut akan meakukan pembelian secara terus menerus. 